\title{
WATER SCARCITY
}

Impacts on Western Agriculture 



\title{
WATER SCARCITY \\ Impacts on Western Agriculture
}

\author{
Edited by \\ ERNEST A.ENGELBERT \\ with \\ ANN FOLEY SCHEURING
}


University of California Press

Berkeley and Los Angeles, California

University of California Press, Ltd.

London, England

(C) 1984 by

The Regents of the University of California

ISBN: 0-520-05300-1 (cloth)

0-520-05313-3 (paper)

Library of Congress Catalog Card Number: 80-048702

Printed in the United States of America

$\begin{array}{lllllllll}1 & 2 & 3 & 4 & 5 & 6 & 7 & 8 & 9\end{array}$ 


\section{The Directorate on Arid Zone Ecosystems of the United States Man and the Biosphere Program Organizing Committee}

Robert M. Hagan - Chairman, Conference Organizing Committee Professor of Water Science and Extension Water Specialist Department of Land, Air and Water Resources

Univeraity of California

Davis, California 95616

Henry P. Caul field, Jr.

Profeseor, Department of

Political Science

Colorado State University

Fort Colline, Colorado

John A. Dracup

Profeasor, School of Engineering

and Applied Science

University of California

Loo Angeles, California

Harold E. Dregne

Director, International Center for Arid and Semi-Arid Land Studieg and Horn Distinguished Professor of Soil Science

Teras Technological University

Lubbock, Texas

Donald Hardesty

Profeesor, Department of Anthropology

Uni versity of Nevada

Reno, Nevada

Charlea Hutchinson

Director, Arizona Remote Sensing Center

Office of Arid Lands Studies

University of Arizona

Tucson, Arizona

Douglas L. Johnson

Associate Profeesor, Graduate

School of Geography

Clark Univenity

Worcester, Massachusetts
Jack D. Johnson

Director, Office of Arid Lands Studies and Adjunct Professor, Department of Soil, Water and Engineering

University of Arizona

Tucson, Arizons

Michael E. Norvelle

Project Director, Cooperative Arid Lands Agriculture Research Program San Diego State University Foundation San Diego, California

Eleonora Sabadell

Program Asociate, Program of Policy Studies in Science and Technology

The George Washington University

Washington, D.C

Gary D. Weatherford

Co-Director, Water Program

Center for Natural Resource Studies

John Muir Institute

Berkeley, California, and

Visiting Professor, School of Law

Univeroity of Santa Clara

Santa Clara, California

Robert A. Young

Professor, Department of Economics

Colorado State Univeraity

Fort Collins, Colorado

\section{California Advisory Committee}

Raymond H. Coppock

Communications Specialist

Cooperative Extension

University of California, Devis

John Cummins

Director, California Policy Seminar

Institute of Governmental Studiee

University of California, Berkeley

Noreen G. Dowling

Director, Public Service Research and Dissemination Program and Lecturer, Department of Applied Behavioral Sciences Univertity of California, Davis

Erneet A. Engelbert

Profeseor of Public Administration Univereity of California, Los Angeles
J. Herbert Snyder

Director, Water Reeources Center and Profesaror of Agricultural Economica University of California, Davis

\section{L.T. Wallace}

Economist, Cooperative Extension Uni versity of California, Berkeley

William W. Wood., Jr.

Program Director, Agricultural Economics and Community Resource Development Cooperative Extension

University of California, Riverside 


\section{SPONSORS}

Organized By:

The Directorate on Arid Zone Ecosystems of

The United States Man and the Biosphere Program

Co-Sponsored By:

University of California

Cooperative Extension

Institute of Governmental Studies

Public Service Research and Dissemination Program

Water Resources Center

University of Arizona College of Agriculture

University of Nevada

University of Nevada at Reno

Desert Research Institute

Clark University

Colorado State University

John Muir Institute

Center for Natural Resource Studies

San Diego State University Foundation

Texas Technological University

International Center for Arid and Semi-Arid Land Studies

With Funding By:

U.S. Man and the Biosphere Program

U.S. Department of the Interior

Office of Water Resources Technology

Bureau of Reclamation

U.S. Department of Agriculture

Science and Education Administration

Soil Conservation Service

U.S. Water Resources Council

University of California Cooperative Extension

BankAmerica Foundation

Farm Foundation

Farm and Industrial Equipment Institute

First Interstate Bank of Arizona

First Interstate Bank of California

First Interstate Bank of Fort Collins

The Ford Foundation

Security Pacific Foundation 